Научная статья

УДК 811.515 .31 '27

DOI: $10.18101 / 2305-459 \mathrm{X}-2020-3-122-128$

\title{
ИЗМЕНЕНИЯ ЛЕКСИКО-ТЕРМИНОЛОГИЧЕСКОГО АППАРАТА БУРЯТСКОГО ЯЗЫКА В ЯЗЫКОВОМ ЛАНДШАФТЕ ГОРОДА УЛАН-УДЭ
}

\author{
(C) Иванов Вячеслав Валерьевич \\ аспирант, \\ Институт языкознания Российской академии наук \\ Россия, 125009, г. Москва, Большой Кисловский пер. 1, стр. 1 \\ vvivanov96@gmail.com
}

Аннотация. Статья посвящена исследованию изменений лексикотерминологического аппарата, а именно общественно-политической лексики бурятского языка как части языковой политики Республики Бурятия. В частности, анализируются цели и механизм таких изменений, а также их проявления в языковом ландшафте на материале вывесок государственных учреждений в центральной части города Улан-Удэ. Исследование показало устойчивую тенденцию к «бурятизации» рассматриваемой терминологии, которая распространяется не только на список утвержденных властью терминов, но и на не вошедшую в нее терминологию. Тем не менее изменения происходят неравномерно: в языковом ландшафте соседствуют «старые» заимствованные и «новые» бурятоязычные термины. Кроме того, в последних наблюдаются явления омонимии и синонимии, которые не должны иметь место в терминологическом аппарате языка.

Ключевые слова: бурятский язык; языковой ландшафт; городское многоязычие; языковая политика; социолингвистика; терминология.

\section{Для цитирования}

Иванов В. В. Изменения лексико-терминологического аппарата бурятского языка в языковом ландшафте города Улан-Удэ // Вестник Бурятского государственного университета. Язык. Литература. Культура. 2020. Вып. 3. С. 122-128.

Развитие лексико-терминологического аппарата бурятского языка и, в частности, его общественно-политической терминологии сопровождалось большими изменениями на протяжении ХХ в. Их механизмы хорошо описаны в трудах таких бурятских ученых, как Т. А. Бертагаев [1], У.-Ж. Ш. Дондуков [2], Ц. Б. Цыдендамбаев [5; 6], а в настоящее время переосмысляются и дополняются в исследованиях С. Д. Чимитовой [7] и Ж. Ш. Санжанова [4]. Тем не менее терминологический аппарат бурятского языка значительно изменился за последние пять лет, что ставит перед властью вопросы его продвижения в общество. Настоящая статья, написанная в русле социолингвистики, представляет собой попытку осмыслить цели этих изменений, а также понять механизмы и степень их распространения в Республике Бурятия на примере города Улан-Удэ.

Изменения в общественно-политической терминологии бурятского языка, которые наблюдаются в настоящее время, инициируются республиканской властью и характеризуются заменой русизмов и интернационализмов на бурятоязычные термины. Такой подход расценивался некоторыми советскими бурят- 
B. В. Иванов. Изменения лексико-терминологического аппарата бурятского языка в языковом ландшафте города Улан-Удэ

скими учеными, в частности, У.-Ж. Ш. Дондуковым [2, с. 8] как «невозможный» и «ненужный», однако не подтверждался какими-либо конкретными аргументами против. Напротив, сам переход на интернационализмы, произошедший после 1930-х гг., доказал, что изменения в этом пласте лексики могут успешно укореняться и распространяться в обществе при грамотном языковом планировании.

В социолингвистической науке существует теория языкового планирования, выдвинутая Х. Клоссом [11, с. 81]. Она выделяет две стороны: планирование корпуса (“corpus planning") и cmamyca ("status planning") языка. Под планированием корпуса языка понимаются изменения, проводимые непосредственно в языке и касающиеся его словарного состава, орфографии, морфологии и т. д., в то время как планирование cmamyca затрагивает функционирование языка и определяет его место среди других языков, используемых сообществом [там же].

Применяя эту теорию на изменения терминологии в бурятском языке, мерой планирования корпуса можно считать разработку «Справочника общественнополитических терминов бурятского языка», который был принят в 2016 г. $^{1}$ В него вошло 122 единицы, которые обеспечили общественно-политическую сферу необходимым набором наиболее часто употребляемых терминов. Дальнейшее же утверждение справочника приказом Министерства образования и науки Республики Бурятия обязало использовать эту терминологию во всех сферах, подчиняющихся действию закона «О языках народов Республики Бурятия», что дает возможность рассматривать его как меру планирования статуса бурятского языка.

Данный справочник разрабатывался с целью «усовершенствования норм современного бурятского литературного языка при его использовании в качестве государственного языка Республики Бурятия» ${ }^{2}$. Кроме того, утверждение новой терминологии вписывается и в политику власти по сохранению, развитию и поддержке бурятского языка в республике, принятую в соответствующем законе в 2014 г. ${ }^{3}$. Такое решение нацелено на укрепление позиций бурятского языка в тех сферах, где он оказывается практически невостребованным: в делопроизводстве, государственном управлении, промышленности, науке, торговле и сфере обслуживания [3, с. 102].

Продвигая новую терминологию, власть в первую очередь начинает использовать ее в собственных учреждениях. Наиболее заметным это становится на их официальных вывесках, которые вместе с другими публичными дорожными знаками, рекламными щитами, названиями улиц, заведений и вывесками магазинов формируют языковой ландшафт данной территории, области или городской аг-

\footnotetext{
${ }^{1}$ Приказ от 29 февраля 2016 года № 376 «Об утверждении справочника общественно-политических терминов бурятского языка». URL: http://docs.pravo.ru/document/ view/84498751/97119846.

2 Приказ от 29 февраля 2016 года № 376 «Об утверждении Справочника общественно-политических терминов бурятского языка». URL: http://docs.pravo.ru/document/ view/84498751/97119846.

3 Закон РБ от 07 марта 2014 года № 383-V «О мерах поддержки бурятского языка как государственного языка Республики Бурятия». URL: http://docs.cntd.ru/document/460281667. 
ломерации $[12$, с. 25]. Языковой ландшафт раскрывает «закономерности социального взаимодействия, в которое вовлечены люди в определенном пространстве» $[10$, с. 3]. Исходя из этого, изменение терминологии на вывесках государственных учреждений можно рассматривать как меру социального взаимодействия органов власти с обществом, на которое и направлены эти изменения. Следовательно, по степени и особенностям распространения и употребления «новой» и «старой» общественно-политической терминологии на рассматриваемой территории можно судить о том, насколько эффективно реализуется проводимая языковая политика.

Данные для настоящей статьи были собраны в январе 2019 г. в центральной части Советского района города Улан-Удэ. Она включает в себя все улицы, расположенные в условном «треугольнике» улиц Борсоева, Смолина и Куйбышева. Этот «треугольник» охватывает большинство главных улиц центра Улан-Удэ, который включает в себя не только деловую, туристическую и административную часть города, но и жилые кварталы. Собираемые единицы языкового ландшафта представляют собой знаки, «содержащие написанный на них текст и имеющие определяемую границу» $[8$, с. 66]. Материал для исследования собирался в течение десяти дней со 2 по 12 января 2019 г. Съемка производилась на цифровую камеру мобильного телефона с 10:00 до 16:00.

Как уже говорилось, в центр внимания настоящего исследования попали знаки, размещаемые государственными учреждениями. По классификации происхождения знаков, предложенной Э. Бен-Рафаэлем, они относятся к группе topdown, так как «подчиняются официальной политике и “доминирующей культуpe”, представляемой официальной властью» [9, с. 49]. Всего в заданной области было обследовано 69 знаков, относящихся к этой группе. Из них заимствования из русского и других языков (русизмы и интернационализмы) используются на 34 знаках, а бурятоязычная терминология на 31. Оставшиеся четыре знака содержат как русскоязычные, так и бурятоязычные термины. Далее на нескольких примерах будет показано, какие особенности наблюдаются в изменениях терминологии бурятского языка в языковом ландшафте Улан-Удэ в последние четыре года.

\section{Яаман министерство}

Данный термин является необходимой частью названий не только министерств, но и подведомственных им учреждений на территории республики. В справочнике он определен как яаман. Его когнатом в халха-монгольском языке является яам, а также письменно-монгольский уaтun, который в Русскомонгольском терминологическом словаре имеет значение 'комиссариат'.

В языковом ландшафте центральной части Улан-Удэ этот термин используется на вывесках следующих министерств ${ }^{2}$ : финансов (мүнгэн һангай яаман), туризма (аяншалгын яаман), спорта и молодежной политики (бэеын тамирай ба

\footnotetext{
${ }^{1}$ Русско-монгольский терминологический словарь / под ред. Г. Р. Ринчинэ. Верхнеудинск: Бургосиздат, 1930. С. 98.

${ }^{2}$ Названия всех учреждений приводятся в оригинальных формулировках с сохранением орфографии и пунктуации источника.
} 
B. В. Иванов. Изменения лексико-терминологического аппарата бурятского языка в языковом ландшафте города Улан-Удэ

залуушуулай талаар яаман), здравоохранения (элүҮрые хамгаалгын яаман), образования и науки (болбосоролой болон эрдэм ухаанай яаман). Старый заимствованный термин министерство встречается в единичных случаях на вывесках таких учреждений, как министерство культуры (соёлой министерство) и министерство экономики (экономикын министерство). Тем не менее терминология на главных учреждениях не всегда согласуется с терминологией, используемой на подведомственных. Например, термин яаман используется на вывеске министерства здравоохранения и на подведомственном ему центре медицинской профилактики им. В. Р. Бояновой, а на другом учреждении - поликлинике № 1 употребляется термин министерство. Есть и обратные случаи: яркий пример - министерство культуры и подведомственный ему хореографический колледж.

Такой же паттерн наблюдается и в парах улас республика, нютагай засагай муниципальна, засагай газар правительство, Ородой Холбооной Улас Россиин Федерации.

\section{Хүтэлбэри захиргаан, эмхи зургаан байгуулга}

Помимо вариативности «интернационализм бурятский термин» наблюдается расхождение и в самой бурятской терминологии при обозначении одного типа учреждения. Примером этому является термин управление, которому в бурятском языке, согласно справочнику, соответствует термин хүтэлбэри. Использование этого термина в таком значении является буквальным переводом с русского языка; халха-монгольский когнат этого термина хөтөлбөр имеет значение 'программа', а в Русско-монгольском терминологическом словаре термину управление соответствует keltes ${ }^{1}$.

Термин хүтэлбэри встречается на вывесках Управления Федерального агентства по управлению государственным имуществом (Гүрэнэй зөөри хүтэлэлгын талаар хүтэлбэри), а также Отдела управления ЗАГС (ЗАГСын хүтэлбэриин mahaz). В то же время на Управлении по чрезвычайным ситуациям используется термин захиргаан (Онсо ушаралта байдалай талаар захиргаан), который в справочнике соответствует русскому термину администрация. Более того, на той же вывеске обозначен орган власти - Администрация города Улан-Удэ (Улаан-Үдэ хотьн захиргаан), которому подчиняется Управление. Следовательно, термин захиргаан употребляется в пределах одной вывески в двух значениях (администрация и управление), что вызывает недопустимую в терминологии неоднозначность. Такое же использование термина встречается и на вывеске Института экономики и управления БГУ (Экономико болон захиргаанай институт)

Другим примером расхождения терминологии является вариативность термина учреждение, которому на бурятоязычных вывесках соответствует байгуулга и эмхи зургаан. Как считает Ж. Ш. Санжанов [4, с. 54], термин байгуулга был вытеснен из употребления термином эмхи 'организация' в конце 1930-х гг. Прибавление к последнему синонима зургаан 'присутственное место, учреждение' [6, c. 518-519] дало в результате утвержденный в справочнике бурятский термин. Вариативность, связанная с употреблением обоих терминов, наблюдается в пре-

\footnotetext{
${ }^{1}$ Русско-монгольский терминологический словарь / под ред. Г. Р. Ринчинэ. Верхнеудинск: Бургосиздат, 1930. С. 7.
} 
делах учреждений, подведомственных министерству культуры: на Бурятском театре драмы в формулировке байгуулга и на хореографическом колледже в формулировке эмхи зургаан.

\section{Дээдэ һургуули институт, ехэ һургуули университет}

Все вышеперечисленные случаи так или иначе содержали терминологию, включенную в Справочник. Однако тенденция изменения терминологии в сторону бурятоязычной наблюдаются и за его пределами. Это хорошо видно на примерах пар дээдэ һургуули институт и ехэ һургуули университет. Такое же распределение терминов существует в халха-монгольском языке (дээд сургууль в значении 'институт' и их сургууль в значении 'университет'), что дает возможность рассматривать данное изменение как влияние родственного языка-соседа на бурятский язык.

Употребление данных терминов варьируется в пределах одного учреждения - Бурятского государственного университета. Так, на вывеске упоминавшегося ранее Института экономики и управления используется интернационализм институт (Экономико болон захиргаанай институт), в то время, как на вывеске Института филологии и массовых коммуникаций используется термин дээдэ һургуули (Хэлэ бэшэгэй болон ниитын харилсаанай дээдэ һургуули).

Другой термин - ехэ һургуули - встречается в названии университета лишь один раз на вывеске общежития № 3 в формулировке Буряад гүрэнэй ехэ hургуули. Остальные же вывески на корпусах и других общежитиях используют старый термин университет (Буряад гүрэнэй университет).

Итак, рассмотренные выше изменения общественно-политической лексики в составе лексико-терминологического аппарата бурятского языка показывают распространение новой терминологии в официальном языковом ландшафте центральной части города Улан-Удэ. Несмотря на то, что в Бурятии существует утвержденный справочник общественно-политических терминов бурятского языка, новая терминология в настоящее время используется далеко не на всех официальных вывесках. Более того, обновление терминов на официальных учреждениях происходит стихийно: в пределах одного органа власти разные учреждения придерживаются разных стратегий: одни уже заменили старые вывески на новые с использованием бурятоязычной терминологии, в то время как другие не спешат делать это (ср. использование терминов яаман и министерство на вывесках поликлиники № 1 и центра медицинской профилактики). Помимо этого в рамках одного учреждения может наблюдаться терминологическая омонимия (ср. захиргаан в значении 'администрация' и 'управление'), а также конкуренция синонимичных бурятских терминов (ср. байгуулга и эмхи зургаан, имеющих значение 'учреждение'). Все это говорит о том, что со стороны власти нет достаточного контроля за обновлением терминологии на государственных учреждениях.

В целом же намеченная тенденция имеет положительный характер, поскольку показывает заинтересованность власти в повышении статуса и расширении функций бурятского языка. Ярким показателем этого является утверждение Справочника общественно-политических терминов. Стоит отметить и то, что такие изменения в сторону бурятизации терминологии происходят и за предела- 
B. В. Иванов. Изменения лексико-терминологического аппарата бурятского языка в языковом ландшафте города Улан-Удэ

ми Справочника: например, термин институт заменяется на дээдэ һургуули, университет - на ехэ һургуули и т. д. Власти следует, с одной стороны, поощрять такие инициативы, а с другой - более пристально контролировать соответствие новой терминологии утвержденным нормам языка. Это подразумевает расширение существующего Справочника, а также выработку общих принципов наименования государственных учреждений на бурятском языке вместе с созданием реестра всех их названий на бурятском и русском языках. При таком более последовательном подходе к планированию и внедрению терминологии можно ожидать ее более быстрое распространение среди носителей и закрепление в бурятском языке в целом, на что и нацеливается языковая политика республики.

\section{Лumepamypa}

1. Бертагаев Т. А. Терминотворчество в бурятском литературном языке. Л., 1936.

2. Дондуков У.-Ж. Ш. О развитии терминологии в бурятском языке. Улан-Удэ, 1970. $80 \mathrm{c}$.

3. Дырхеева Г. А. Языковые приоритеты Республики Бурятия: система образования // Языковая политика и языковые конфликты в современном мире (международная конференция). 2014. С. 101-107.

4. Санжанов Ж. Ш. Формирование общественно-политической лексики бурятского языка на монгольской письменности в 20-30-е г. г. XX в.: дис. ... канд. филол. наук. Улан-Удэ, 2017. 185 c.

5. Цыдендамбаев Ц. Б. Об общественно-политической терминологии в бурятмонгольском языке: сб. трудов по филологии. Вып. 1. Улан-Удэ: БурМонгиз, 1948. C. 3-30.

6. Цыдендамбаев Ц. Б. Бурятские исторические хроники и родословные. Улан-Удэ: Бурят. кн. изд-во, 1972. 662 с.

7. Чимитова С. Д. Словообразование общественно-политической лексики монгольских языков // Вестник Бурятского государственного университета. Педагогика. Филология. Философия. 2010. № 8. С. 138-143.

8. Backhaus P. (ed.). Linguistic landscapes: A comparative study of urban multilingualism in Tokyo. Multilingual Matters, 2007. Vol. 136. 158 p.

9. Ben-Rafael E. A sociological approach to the study of linguistic landscapes // Linguistic Landscape. Routledge, 2008. P. 48-62.

10. Blommaert J., Maly I. Ethnographic linguistic landscape analysis and social change: A case study // Tilburg papers in culture studies. 2014. Vol. 100. P. 1-27.

11. Kloss H. Research Possibilities on Group Bilingualism: A Report. 1969. 91 p.

12. Landry R., Bourhis R. Linguistic landscape and ethnolinguistic vitality: an empirical study // Journal of Language and Social Psychology. 1997. Vol. 16. P. 23-49.

\section{CHANGES IN THE BURYAT LANGUAGE VOCABULARY IN THE LINGUISTIC LANDSCAPE OF ULAN-UDE}

Vyacheslav V. Ivanov

Research Assistant,

Institute of Linguistics, Russian Academy of Sciences

1/1 Bolshoy Kislovsky Lane, Moscow 125009, Russia

vvivanov96@gmail.com 
Abstract. The article is devoted to the study of changes in the lexical and terminological apparatus, namely, the socio-political vocabulary of the Buryat language. These changes are perceived as part of the language policy of the Republic of Buryatia. In particular, the author analyzes the purpose and mechanism of such changes, as well as their manifestations in the linguistic landscape (signs of state institutions) of the central part of UlanUde. The study showed a steady tendency towards "Buryatization" of the terminology under consideration, which applies not only to the list of terms approved by the authorities, but also to terminology that is not included in it. Nevertheless, the changes are taking place unevenly: in the linguistic landscape, "old" borrowed and "new" Buryat terms coexist. In addition, in the latter terms, there are observed the phenomena of homonymy and synonymy, which should not take place in the terminological apparatus of the language.

Keywords: the Buryat language; linguistic landscape; urban multilingualism; language policy; sociolinguistics, terminology.

Статья поступила в редакцию 26.10.2020; одобрена после рецензирования 13.11.2020; принята к публикациии 01.12.2020. 